\title{
Assessing The Contribution of The People's Education Program (Prodira) Policy Toward Senior High School Education Performance in Gorontalo Province
}

\author{
Arwildayanto \\ Department of Education Management, Faculty of Education Sciences \\ Universitas Negeri Gorontalo \\ arwildayanto@ung.ac.id
}

\begin{abstract}
The purpose of the study is to assess the effectiveness of people's education program (PRODIRA). The study used a mixed research methods approach with concurrently embedded, combination model of the qualitative and quantitative methods. The data were collected using interview, documentation and observation techniques from respondents who included headmasters, teachers, exchequers, students' parents and school committee members in senior high schools, vocational and Islamic senior high schools (SMA/SMK/MA) in Gorontalo Province. The results indicated that the implementation of PRODIRA program by the Provincial Government of Gorontalo has been effective in enhancing quality of performance of Senior High School Education (SLTA) in Gorontalo Province as reflected in the increase of knowledge index, increased availability of SMA/SMK/MA institutions, percentage of schools that are categorized as being in good condition and a decline in school dropout rates.
\end{abstract}

Keywords: education performance, policy effectiveness, PRODIRA 


\section{INTRODUCTION}

Article 34 of Law No. 20/2003 on National Education System, stipulates that (1) Every citizen at the age of six can enroll in a compulsory basic education program, (2) The central government and local governments guarantee the implementation of compulsory education at least for basic education free of charge, (3) It is the responsibility of the State, local govern-ments, and the community to provide compulsory education (Ali, 2009; Sidik, 2015). Thus, the law has implication that the central and local governments have the obligation to provide the funds necessary to finance the implementation of the nine-year compulsory education in the Regional LongTerm Development Plan (RPJP), Regional Medium-Term Development Plan (RPJM), Strategic Plan (RENSTRA), Regional Revenue and Expenditure Budget (APBD), and Local Government Work Plan (RKPD) in the filed of Education in all local governments (Ashari, 2016). This is in line with Government Regulation No. 47/2008 on Compulsory Education as the minimal education attainment for every Indonesian citizen.

The thrust of the basic education provision policy is to improve the quality of Indonesian human resources measured by attainment of a minimum standard as formulated in the Government Regulation No.19/ 2005 on National Education Standard (SNP). The regulation sets the vision on the standard and quality of education, lays down the strategies and concrete steps required to develop it, including the political will of the government and local governments in implementing compulsory primary education (Karding, 2008). In line with Government Regulation No. 47/2008 on Compulsory Education in Article 7, Paragraph (4) that vests the responsibility of providing compulsory primary education with local governments, and Paragraph (5) on the implementation of the nine-year compulsory education program, Gorontalo provincial government has implemented the 12-year compulsory education program. Based on Gorontalo Province vision to create an Advanced and Independent province and Gorontalo's long term development plan for 2007-2025, the local government has taken various steps to accelerate the provision of compulsory primary and secondary education. The focus on education has been motivated by the desire to create reliable human resources in Gorontal province. Gorontalo provincial government policy on accelerated education provision is contained in local government No. 2/2012 on the RPJM 2012-2017 for the provincial administration Agency for Education, Culture, Youth and Sports (DIKBUDPORA). That sets education as a priority development program. The regulation underlines the commitmemt of the provincial government to implement the nine-year compulsory education program as mandated by the central government. Besides, Gorontalo provincial government has also issued Gobernatorial Regulation No. 9a/2012 on the implementation of Free Education for Senior High School students code named PRODIRA, which is a pioneering effort to provide 12-year compul-sory education to high school students in the province.

PRODIRA policy is based on funding for program operations that are provided by Gorontalo provincial government in accordance with Gorontalo Provincial governor Regulation No. 6/2015 on implementing education delivery, while the providing compulsory primary education remains the responsibility of the central government, district or city governments (Handayani, 2012). Some of the problems that education provision face in the province, as disclosed by Arsyad (2016) explained which motivated the provincial government take action, included limited access of primary school pupils who completed their education to join secondary schools due to distance and remote locations, low School Participation Rate (APS), high secondary education dropout rate, and inadequate educational scholarship programs for low-income communities, paying operating unit cost of education, and individual 


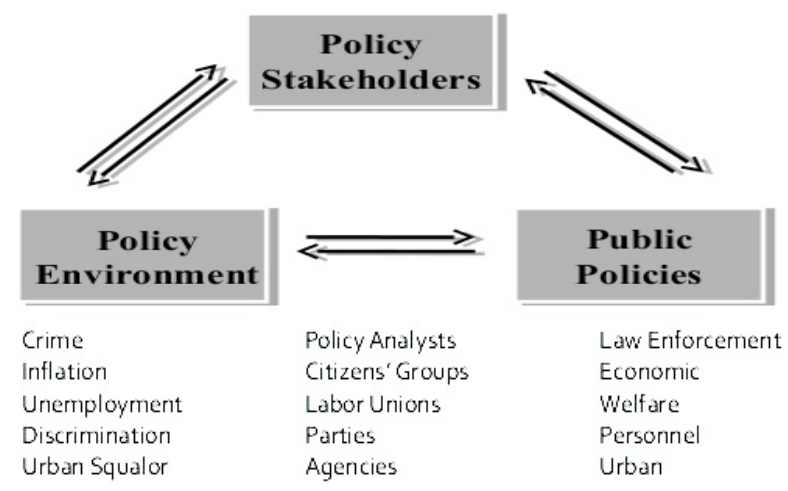

Figure 1. Three Elements of Policy System Source: Thomas R. Dye, 1978

cost and investment cost children are required to pay. PRODIRA policy attempts to reduce the cost barriers poor families face so that all high school-age children have access to set minimum 12 year education services.

Wenni Liputo (2017) gave a similar explanation to the effect that the PRODIRA program was a response to the need for pro people education policy by among other things reduce the financing cost that parents meet to pay for secondary school education of their children.

Previous research on education access shows that among other factors, absence pro people education policy, has led to poor education outcomes (Suprastowo, 2014). To that end, the implementation of the policy should eliminate obstacles that relate to the cost of financing school by parents for their children. Consequently, the number of students from low income families who attend secondary should increase.

PRODIRA policy entails Gorontalo government efforts to provide financing for education provision for high school students with the goal of ensuring that all high schoolage children have access to 12 year education. The expectation is that the implementation, of the policy, should increase knowledge and skill level, higher self-esteem and personal development, self-esteem, and an enhanced human resource pool in the province, which in turn should contribute to higher earning power, income, and societal welfare (Prasojo, 2012; Gaffar, 2007; and Imron, 1996).

PRODIRA program can viewed as an outcome of a framework that involves policy stakeholders, policy environment and public policy (Figure 1). Thus, PRODIRA program is a focused strategy of the Gorontalo Provincial Government on one aspect of education delivery in the province (access to high school education), which this far has hampered government efforts to achieve long term goals of quality resource development that is in turn crucial for realizing the ultimate goal of any government increasing societal welfare of its citizenry (Widaningrum, 2007).

The effectiveness of PRODIRA policy can be measured using the benefit cost ratio of the present value of program return on investment and expenses (Fattah, 2008). Benefits include improvement in education quality, supplemented by the increase in the number of education attainment in the population with secondary and higher education (12 year-compulsory education), political will and discretion of Gorontalo of the Provincial Government as public policy actors hence formulators of PRODIRA education policy.

With respect to education financing, PRODIRA policy is in line with the Law on National Education System No.20/2003 that mandates the ntional government to allocate $20 \%$ of annual national and local government expenditure on education. The underlying goal 
of the provision is to ensure that Indonesians have access to education including, the availability of quality, and affordable education services in a certain manner (Ferdi, 2013).

Theoretically, PRODIRA has adopted two models of education financing, inter alia the Equalization Model and Foundation Plan Model. The Equalization Model is based on the people's ability to pay. The model requires the government to provide more financial assistance to children who hail from poor families than those who are from high income families. Thus, the program makes possible poor schools to have an equal opportunity with other schools (Boadway, 2004; Hoxby, 2001; Lunenburg et al., 2008). Meanwhile, based on the Foundation Model, the central government sets the minimum education attainment limit, in this case the nine-year compulsory education, and since 2016, the 12year compulsory education limit, for all children. Local governments are allowed to establish education programs that set higher compul-sory limits above those set by the national government, based on their ability and capacity. The working procedures of the Foundation Plan Model are: 1) the national government determines the cost for each student per year of the educational program; 2) the national government sets the minimum tax rate to assign to all schools; and 3) the national government allocates the same amount to each school. The level of assistance is situational in accordance with the prosperity and wealth of the region, rather than tax effort. It is also worth noting that the Foundation Plan provides the same level of assistance to all provinces, with poor provinces being given priority (Syakdiah, 2005).

To that end, Gorontalo provincial government embarked on PRODIRA program, which is tailored toward increasing access and affordability of high school education in the province. The policy is in line with the national mandate, discretion that the Law on national education affords local government, and political will of Gorontalo provincial government. The objective of this paper is to assess the performance of PRODIRA program in accelerating the performance of secondary education in Gorontalo Province. Assessing program effectiveness will be based on an evaluation of budget and reports (documenttation), in-depth interviews with relevant officials and observation (Soehartono, 2007).

\section{Description of PRODIRA program}

PRODIRA, was an initiative of Rusli Habibie, as the Governor of Gorontalo, which was aimed at improving the quality of education, which in 2013 was still far below national average. The program provides funding for operational costs of high schools that are specified in the regulation on which it is based. To gauge the effectiveness of PRODIRA, there is need to understand procedures and strategies that have been put in place to formulate and implement the program. PRODIRA program is based on Regional Regulation No. 7/2012 on the implementation of PRODIRA, specifically Chapter I on the general provision, article 1 , that stipulates that PRODIRA entails the implementation of education program that exempts students from paying operational costs to secondary education units with the exception of International School Stubs (RSBI), International Standard School (SBI), and educational units that are managed by the community.

PRODIRA policy objectives are underlined in the instruction issued by the Gorontalo Province Head of Dikbudpora No.188.4/Dikbudpora/172.a/Secondary Education/I/2014 which stipulates, a) providing education services for the entire community of Gorontalo Province that includes child-hood education (PAUD), primary education, and secondary education with the purpose of developing their potential to become independent individuals and continue their education to higher level; b) increase the participation rate of early childhood education, primary and secondary education; c) to create quality and relevant education by improving education services at all levels of education; and d) to provide education free of charge for all of the students 




Figure 2. Budget allocation for PRODIRA program for 2011 to 2016 Source : DIKBUDPORA Gorontalo Province, 2016

with respect to operational cost of education unit (DIKBUDPORA, 2014).

The level of APBD spent over the last five years to implement the PRODIRA policy underscores the importance that Gorontalo province attaches to education as one of the leading sectors. Figure 2 shows the amount of APBD spent over the last five years on PRODIRA program.

Conducting an assessment of the effectiveness of PRODIRA policy is not only aimed at determining the extent to which the program is achieving its goals and targets, but also to gauge the extent to which the program is contributing to improving the quality of education in the province. The assessment of program effectiveness also serves a reality check on whether the program costs are justifiable based on benefits and values the program has generated (Sri, 2014; Putri and Ratnawati, 2011).

Robbins (1990) defines effectiveness as a level at which an organization or institution can realize its objectives. In the same vein, Carl Friedrich in Wahab (2004) notes that an effective policy should achieve goals that a person, group/government in a particular environment proposed it will achieve as well as opportunities proposed to actualize the desired target. Moreover, Mahmudi (2005) in Adhayani and Kusumah (2015) states that the larger the output of the program hence goal achievement, the more efficient the organisation, program or activity will be.

Siagian (2001) in Sri (2014), on the other hand, defines effectiveness as utilization of certain predetermined amounts of resources, facilities, and infrastructure to generate targets for the number of goods or services of activities it carries on. Effectiveness indicates success in terms of whether or not the target has been achieved and determined. If the outcome of the activity is closer to the target, it means that it arrives at its effectiveness.

From above description, an inference can be drawn that the effectiveness of PRODIRA policy is the extent to which the policy aligns with various existing regulations and national education objectives on enhancing the quality of Senior High School Education (SLTA). On that ground, effectiveness of the program can be gauged by the impact it has on improving education quality, improvement in living standards and contribution to increasing public participation in financing education. The implementation of the program takes into consideration the required cost components, socialization, and transparency. This is important to avoid deviations that supervisors may do while conducting monitoring, evaluation of the original and follow-up programs. 


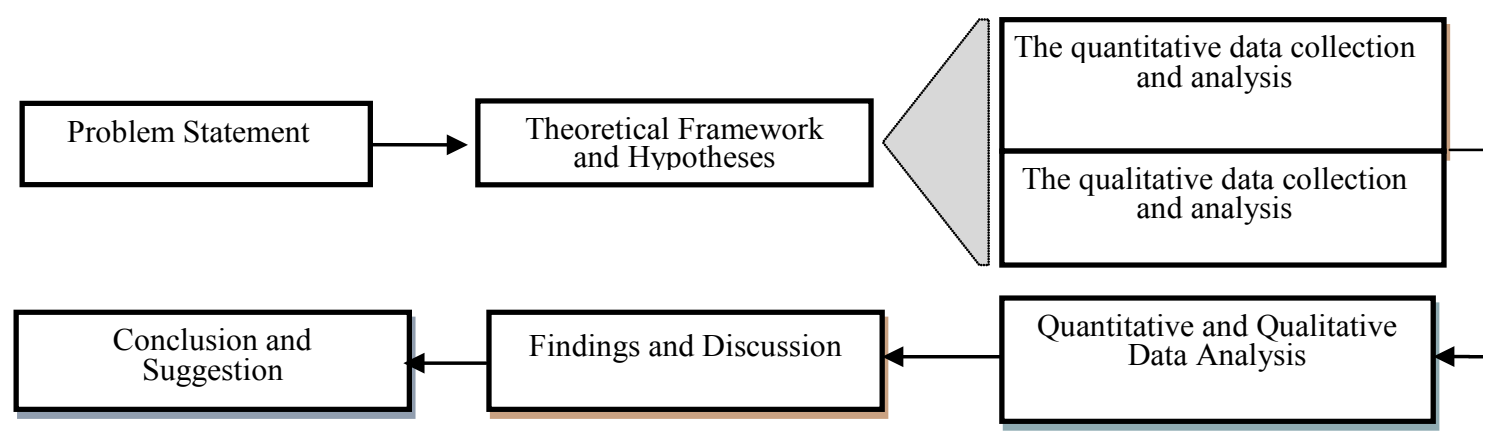

Figure 3. Combined Research Method of Concurrent Embedded Source: Sugiyono (2016)

\section{METHODS}

This study used a mixed methods approach that included qualitative and quantitative method (Frianti, 2012). The research design is based on a concurrent embedded combination model. According to Sugiyono (2016), a concurrent embedded design is a research strategy that combines quantitative and qualitative research by combining $70 \%$ of the quantitative methods with $30 \%$ of the qualitative methods or vice versa, as shown in Figure 3.

The population in this study included headmasters, teachers, exchequers, parents of students or school committee members from 155 SMA/SMK/MA in Gorontalo Province. The sample was based on probability sampling technique, which gave equal opportunity for every member of the population (Sugiyono, 2016). This study selected 32 schools, which comprised $20 \%$ of the population (Setiawan \& Hariyono, 2013). Using a simple random sampling method, 116 respondents were selected for interview. The interview was based on a snowball technique of key informants. Results of indepth interview were complemented by observation and documentation.

Pearson Product Moment formula with SPSS version 20.00 was used to test instrument validity. Using the correlation term of each positive factor and magnitude of 0,361 and above as indicative of a strong construction and good validity. Meanwhile, to test reliability of the instrument, the research used Alpha Cronbach formula with SPSS version 20.00.
Results of reliability test was $r=0.961$, which is a magnitude that attests to high reliability.

Data analysis entailed several stages that included 1) statistical analysis 2) descriptive analysis. The statistical analysis consists of 1) data selection and classification, 2) data processing, data organizing by calculating the total score of items on the questionnaire and respondents' score, which was calculated using Weighted Means Scores (WMS) as explained by Sudjana (2005):

$$
\bar{x} \bar{x}=\frac{X i X i}{N N}
$$

Information:

$\bar{x} \bar{x}=$ Average Score

$\mathrm{X}_{\mathrm{i}}=$ Total aggregated score (frequency result with the score item for each alternative answer)

$\mathrm{N}=$ Total respondents

The next step is calculating the percentage

$(\%)$ of each indicator with (\%) formula:

$P=\frac{F}{N} \times 100 \%$ and converted to

$\mathrm{X}=\frac{\sum(F, R)}{N} \times 100 \%$

Information:

$$
\begin{array}{ll}
\mathrm{P} & =\text { percentage } \\
\mathrm{X} & =\text { Average } \\
\mathrm{F} & =\text { Frequency } \\
\mathrm{N} & =\text { Total Respondent } \\
\Sigma(\mathrm{F} . \mathrm{X}) & =\text { The Score of Answer Category }
\end{array}
$$


Table 1. Variable Score Frequency Distribution of the Effectiveness of PRODIRA Policy

\begin{tabular}{ccccccc}
\hline No & Interval & $\begin{array}{c}\text { Absolute Frequency } \\
(\mathbf{F a})\end{array}$ & $\begin{array}{c}\text { Relative Frequency } \\
(\mathbf{F r})\end{array}$ & $\mathbf{X}$ & $\mathbf{F x}$ & $\mathbf{F x}(\mathbf{x})$ \\
\hline 1 & $103-121$ & 1 & 0,9 & -5 & -5 & 25 \\
2 & $122-140$ & 7 & 6,0 & -4 & -28 & 112 \\
3 & $141-159$ & 17 & 14,7 & -3 & -51 & 153 \\
4 & $160-178$ & 18 & 15,5 & -2 & -36 & 72 \\
5 & $179-197$ & 16 & 13,8 & -1 & -16 & 16 \\
6 & $198-216$ & 23 & 19,8 & 0 & 0 & 0 \\
7 & $217-235$ & 15 & 12,9 & 1 & 15 & 15 \\
8 & $236-254$ & 18 & 15,5 & 2 & 36 & 72 \\
9 & $255-263$ & 1 & 0,9 & 3 & 3 & 9 \\
& & $\mathbf{N}=\mathbf{1 1 6}$ & & & $\Sigma \mathrm{fx}=-82$ & $\Sigma \mathrm{fx}^{2}=474$ \\
\hline
\end{tabular}

The researcher used the mean of respondents, alternative answer in accordance with the criteria with the following range 86$100 \%=$ very good, $76-85 \%=$ good, $60-75 \%$ $=$ fair, $45-59 \%=$ poor and $<45 \%=$ very poor (Sudjana, 2005).

\section{FINDINGS AND DISCUSSION}

The results show that variable scores that measure the effectiveness of PRODIRA policy are: maximum score $=256$, minimum score $=$ 103 , mean $=194$, percentage of average score and maximum score comparison $=194 / 256$ x $100=75,78 \%$, mode $=152$, median $=197$, sample variance $=132,68$, deviation standard $=36,34$ and range $=153$. Variable frequency distribution of the effectiveness of PRODIRA policy can be observed in table 1 .

The absolute frequency data of effectiveness of PRODIRA policy are 23 respondents $(19,90 \%)$ for the average group, 15 respondents $(12,90 \%)$ for the above average group, and 16 respondents $(13,80 \%)$ for the below the average group. The recapitulation of data on PRODIRA policy effectiveness variables $82,72 \%$, which put it into good category as shown in table 2 .

Based on statistics on state high school performance for instance Headmaster SMA Public 1 Telaga Biru Gorontalo district, PRODIRA policy has contributed to improving the performance of secondary education performance in the province.
PORIDRA program has in turn contributed to an general increase in educational attainment of the population in Gorontalo province, which has in turn led to an improvement in knowledge index during 2013-2016, which happened to be the tenure of Governor leadership. Moreover, thanks to PRODIRA program, public confidence in the ability of school management to manage funding has increased (RDWK/TC/2017 adopted from Sumar, 2017).

The results of this study are also in line with Sumar (2017) research findings that showed that the implementation of PRODIRA in selected high schools in Gorontalo Province has been able to improve the condition of education service delivery through increasing support by $75 \%$, increase in education index by $63 \%$, and contribution to Gorontalo province superior program by $72 \%$. Similarly, the Head of Dikbudpora Gorontalo Province, Weny Liputo (2016) confirmed the positive contribution that PRODIRA policy has made toward HDI Gorontalo. This is based on the increase in length of average schooling, which has surged by about 8,2 years since 2010. Besides, based on data obtained from the Central Bureau of Statistics (BPS) (2015), the length of average schooling in Gorontalo province is 12,88 years, making it higher than national average of 9,2 years. The above results coroborate Astri, Nikensari and Kuncara (2013) findings that showed that an increase. 
Table 2. The Score Recapitulation of PRODIRA Effectiveness with concurrent embedded combination model (Quantitative and Qualitative Analysis Result)

\begin{tabular}{|c|c|c|c|}
\hline No & Aspect & $\begin{array}{c}\text { Quantitative } \\
\text { Analysis Result } \\
\end{array}$ & Qualitative Analysis Result \\
\hline 1 & $\begin{array}{l}\text { The Equality } \\
\text { of PRODIRA } \\
\text { Policy }\end{array}$ & $\begin{array}{c}89,19 \\
\text { (Very Good) }\end{array}$ & $\begin{array}{l}\text { The regulations governing PRODIRA policy include technica } \\
\text { guidance, regional regulations, governor's regulation, the policy } \\
\text { is in accordance with the National law on education system }\end{array}$ \\
\hline 2 & $\begin{array}{l}\text { Target } \\
\text { Achievements }\end{array}$ & $\begin{array}{l}78,24 \\
(\text { Good })\end{array}$ & $\begin{array}{l}\text { The achievement with respect to improving the knowledge Index } \\
\text { for the province, an increase in APK, APM, APS, Graduation } \\
\text { rate, decrease in dropout rate (DO), reducing illiteracy and } \\
\text { completion of 12-year compulsory education }\end{array}$ \\
\hline 3 & Management & $\begin{array}{l}81,17 \\
(\text { Good })\end{array}$ & $\begin{array}{l}\text { Degree to which school Management refers to technical guidance } \\
\text { and has flexibility in using or targeting PRODIRA funds from } \\
\text { eight national education standard }\end{array}$ \\
\hline & Monitoring & $\begin{array}{l}82,26 \\
(\text { Good })\end{array}$ & $\begin{array}{l}\text { Monitoring through evaluation and monitoring actions have run } \\
\text { well in accordance with PRODIRA technical guidance }\end{array}$ \\
\hline & Average Score & $\begin{array}{l}339,86 / 4=82,72 \\
\quad(\text { Good })\end{array}$ & $\begin{array}{l}\text { Qualitatively, PRODIRA policy runs well in accordance with the } \\
\text { regulation in achieving the set targets and objectives, conducting } \\
\text { managing and monitoring functions in accordance with the } \\
\text { technical guidance. }\end{array}$ \\
\hline
\end{tabular}

Ekosiswoyo (2008) shows that economic benefits derives from investing in education (rate of return) such as PRODIRA policy are higher than those from physical investments with an average ratio of $15,30 \%$ and $9,10 \%$, respectively. Thus, Gorontalo Government policy to invest in education through PRODIRA policy is appropriate and effective in improving the ability and capacity of the young generation in becoming more productive to the regional economy. The investment policy through PRODIRA undertaken by Gorontalo Provincial Government is also in line with the basic assumption of Human Capital theory, which associates attainment of education with increase in personal incomes. Every additional year of schooling, postpones earned income revenue by a year, but also contributes to an increase in work skills, productivity, and income levels (Atmanti, 2009).

Thus, in general, PRODIRA policy, which exempts SMA/SMK/MA students from paying operational costs in schools has contributed significantly to improving the performance of senior secondary education. Indicators of such improvement is discernible from the following aspects:

\section{The Knowledge Enhancement Index}

The effectiveness of PRODIRA policy has led to an increase in Knowledge Index for in Gorontalo Province, which based on BPS Gorontalo (2017), the increase in the Knowledge Index is associated with an increase in the capacity of the population to acquire and make use of knowledge. Knowledge acquisition and use is gauged by the increase of the length of Schooling on Average (RLS) and School Expectation (HLS). Figure 3 shows statistics on the two indicators for Gorontalo province (Arwildayanto, 2017).

The main impact of the PODIRA is on increase of knowledge index in Gorontalo province. Beside, the knowledge index, PRODIRA program has also side impact in term of increasing the quality of education infrastructures both in SMA and SMK, decrease the dropout rate as well as increase the student enrol and improve the teaching and learning performance in the school.

\section{A Better Availability Ratio of Senior High Schools (SMA), Vocational Schools (SMK) and Islamic High Schools (MA).}

School availability ratio of SMA/ MA/ SMK in accommodating people who fall under 


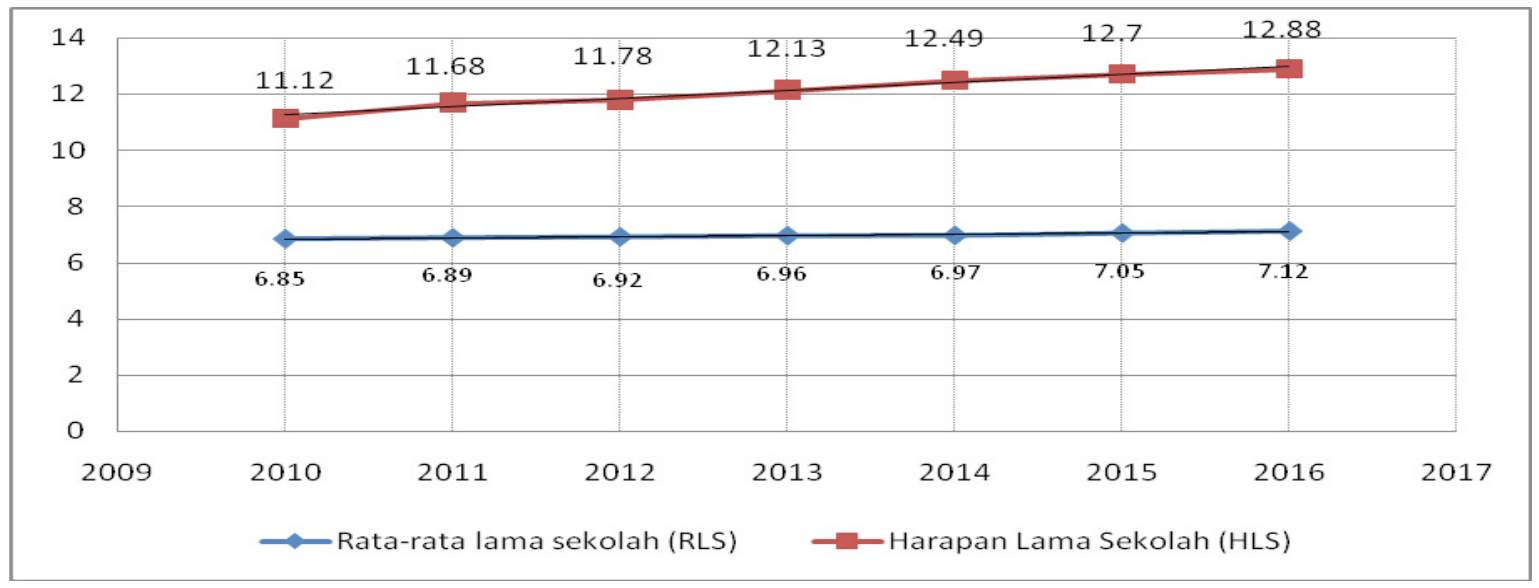

Figure 4. The Trend in the Increase of RLS and HLS in Gorontalo Province in 2010-2016 Source : BPS Gorontalo, 2017

16-18 age bracket is defined as the number of schools based on the education level per 10,000 population of education age. The ratio of school availability for Gorontalo province has been increasing every year during 2012-2016 period. In 2016, the ratio of SMA/MA/SMK school availability in Gorontalo Province was $1: 26,51$, which means that one school can now accommodate 27 students. In 2016 the schoolage ratio was 15,75 students, while available slots in schools was for 26.51 or 27 students for each school. This implies that PRODIRA has created a positive impact of as many as 7 out of 10 persons for the 16-18 age group to attend high school. Thus, thanks to the support that PRODIRA program has provided, 16-18 year olds have better access to affordable high school education (BPS Gorontalo, 2016).

\section{The Percentage of SMA/SMK Schools in Good Condition}

The percentage of SMA/SMK schools in good condition also shows a positive trend. Such evidence is discernible in Dikbudpora performance report (2016), which shows that the percentage of SMA/MA categorized as good condition stands at $93 \%$ of similar schools in Gorontalo. It is also worth noting the improvement in school condition achieved so far exceeded expectations of 91 percent for 2017. In other words, with respect to improving the condition of SMA/MA in
Gorontalo, thanks to PRODIRA program, it is currently at $102,20 \%$ of pre-determined target. Thus, the performance level toward the end of RPJMD in 2017 stood at $92 \%$, an achievement of $101.09 \%$ of the pre-determined target for the period. This is contrast with achievement for 2014 and 2015 , which was $90,28 \%$ and $91,22 \%$, respectively, respectively. Figure 4 shows a detailed account of the trend in percentage of SMA/MA schools that met the category of 'good condition' during 2012-2016 period.

\section{The Percentage of SMK Schools in Good Condition}

The trend in the percentage of SMK schools in good condition serve as an indicator of improvement in the performance of secondary education technical schools (SMK). In 2016, the target set of 93,60\% for the period was reached, which exceeded predetermined target of $87,00 \%$. The implication is with respect to improving SMK schools in good condition in Gorontalo, by 2016, progress has achieved $107,59 \%$ of expected target. The achievement toward the end of RPJMD in 2017 had surpassed the target of $88 \%$, that is registered an achievement result of 101,09\% (1,09 percent above set target). This in contrast with achievement for 2014 and 2015 of $93,73 \%$ and $94,52 \%$, respectively. Figure 5 shows the 


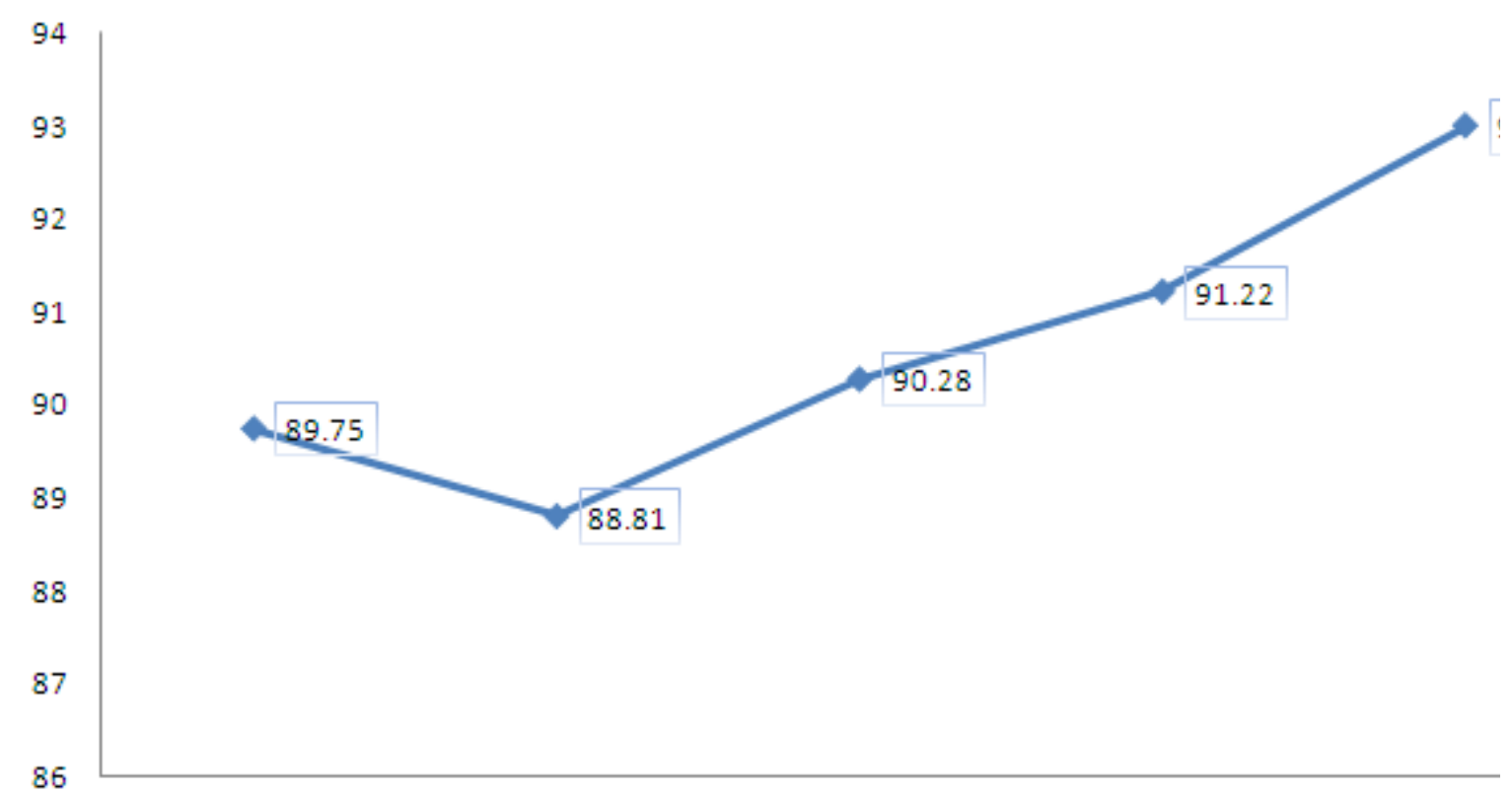

Figure 5. The Percentage of SMA/MA Schools in Good Condition in Gorontalo 2012 to 2016 Source: Dinas Dikbudpora Gorontalo Province, 2016

trend in percentage of SMK schools in good condition during 2012-2016 period.

\section{The Decrease in SMA/MA/SMK Dropout Rates}

The quality of secondary education is also evident in the percentage of high school dropout in the province. In 5015, Gorontalo province achieved SMA/MA/SMK dropout rate of $0,01 \%$, which was twice the set rate of $0.02 \%$ for the year. Programs that have contributed toward the decline in dropout rate at high schools include the School Operational Assistance Program (BOS-SM), Low Income Student Assistance (BSM), high school equivalency education program and the PRODIRA.

The dropout rate of secondary education students has declined in successive years during 2012-2016 period. In 2012, the dropout rate was $0.70 \%$, and dropped to $0,31 \%, 0,14 \%$, $0,01 \%$, and $0,01 \%$ in $2013,2014,2015$ and 2016, respectively. Figure 6 shows the trend in SMA/SMK/MA dropout rate during 20122016 period.
The Increase in the Percentage of Students who Continue SMA/SMK and MA Levels Education

The percentage of students who continue with SMA/MA/SMK education also reveals a positive trend that has exceeded the target for the period. The target achieved in 2016 was $65.76 \%$, which was $0.04 \%$ higher that the set target for the year $(65 \%)$. This development underscores the fact that Gorontalo population has become more enthusiastic to continue and finish their secondary education. The enthusiasm to pursue education, moreover, does not stop at high school but has also become increasingly evident at University level. Thus, the policy of the Gorontalo provincial government to increase access to high education, has changed people's perspective and worldview on the importance and value of higher education.

To that end, it is not an overstatement that Gorontalo provincial government PRODIRA policy by providing subsidized education to the population has injected long term investment into the society which has not only affected current students by attending secondary education and beyond, but also more importantly, changing people's attitudes 


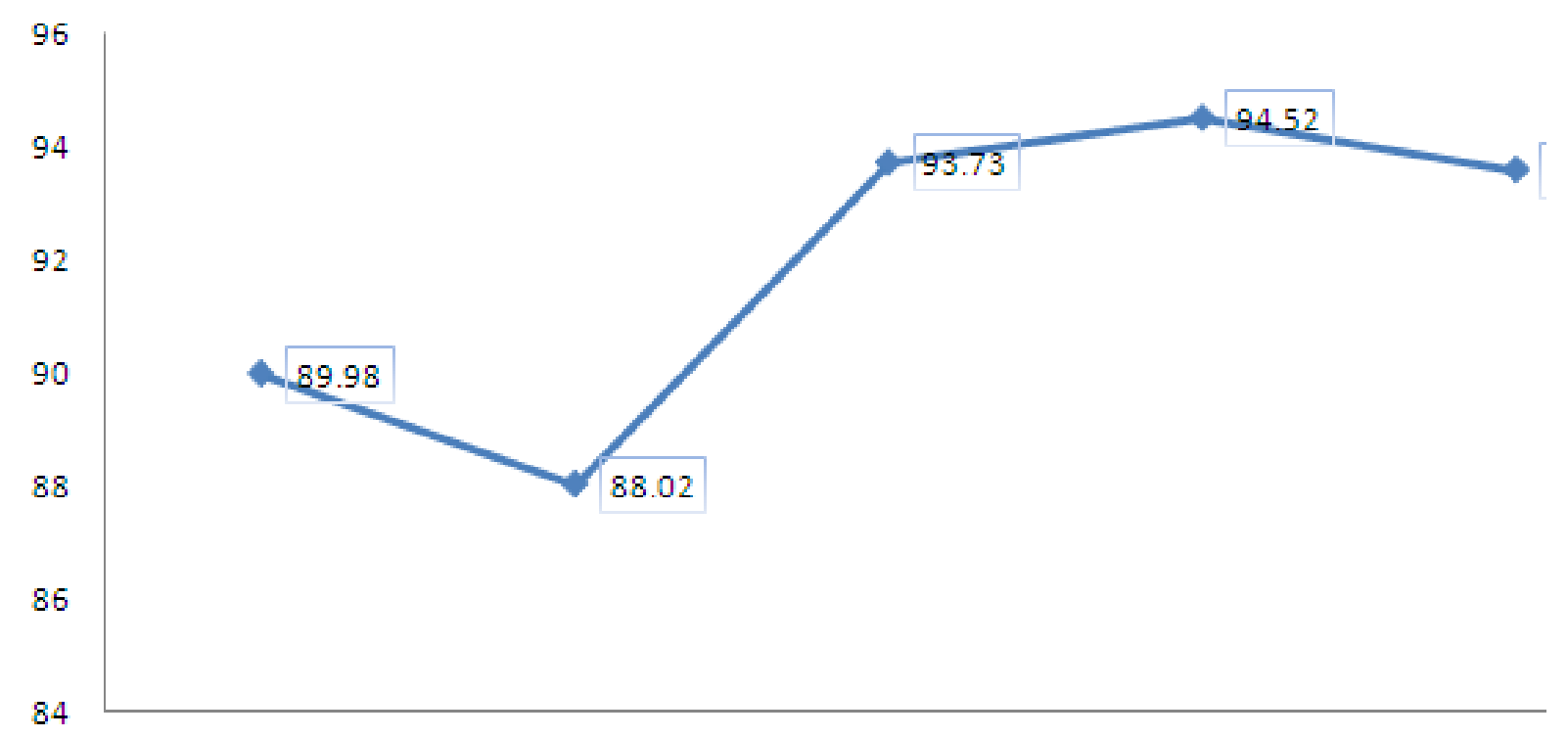

Figure 6. The Percentage of SMK Schools in Good Condition 2012 - 2016

Source: Dinas Dikbudpora Gorontalo Province, 2016

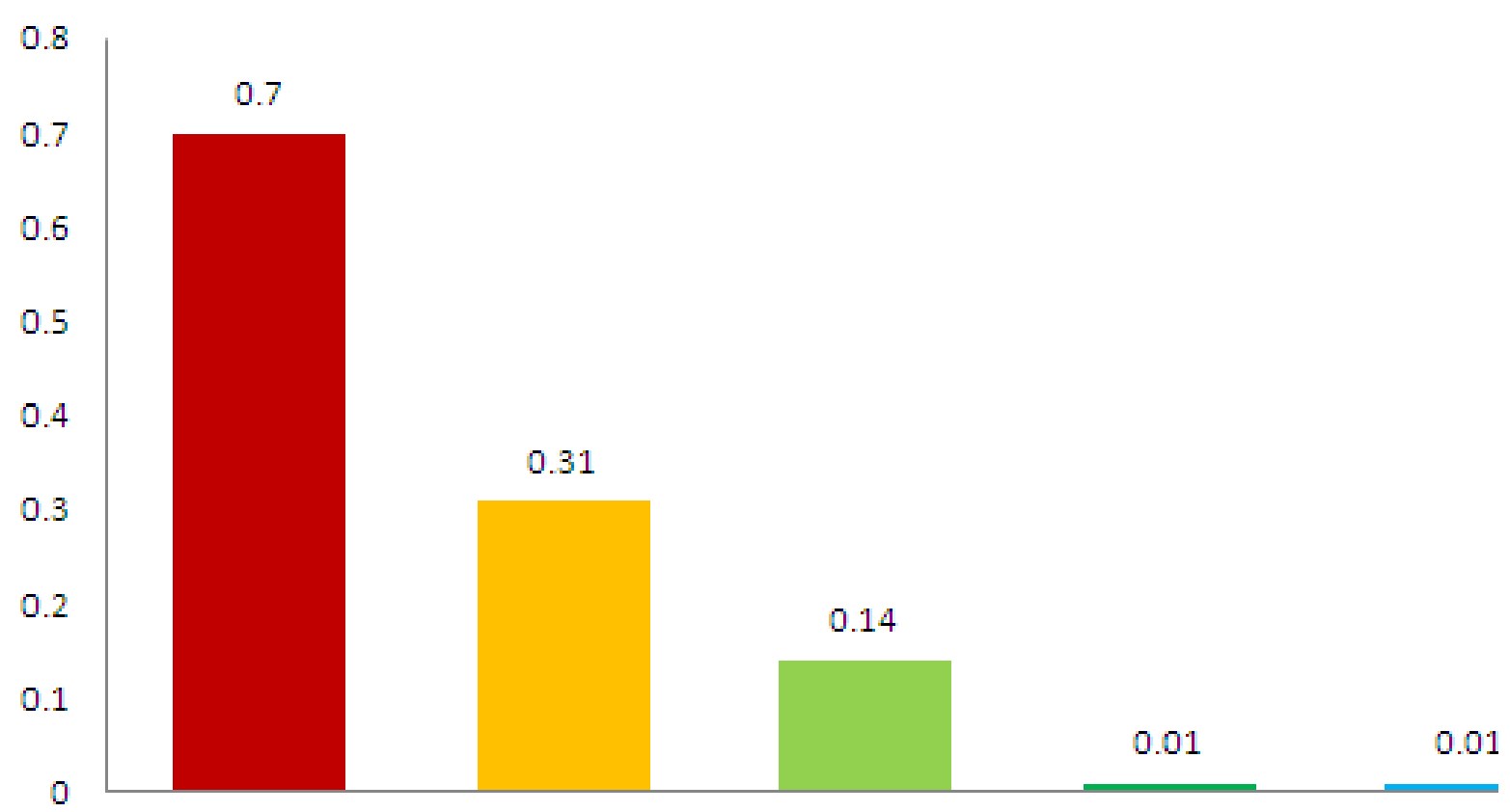

Figure 7. The Trend in SMA/SMK/MA Dropout Rate in Gorontalo Province during 2012-2016 period Source: Dinas Dikbudpora Gorontalo Province, 2016

about the benefits that education generates for them and society as a whole (Astri, Nikensari, and Kuncara, 2013). Study results showed proof that government expenditure on education contributes significantly to education quality. This was reflected in the significant influence that some independent variables that represented government expenditure on improved education performance ( $\mathrm{T}$ count 3,023>t table 1, 674116).

Investing in education is in consonance with World Bank recommendation that underlines the positive effect on investment in education on edulation quality which was issued as far back as 1960. The Recommndation set out four criteria for human resources development, 
including 1) the needs of skilled workers in vocational and technological fields; 2) the expansion of primary and secondary education; 3) the rate of return related to the lower costs; 4) justice that arises from the distribution of educational opportunities and other forms of human resources development geographically, socially and economically (Psacharopoulos, 1994). Better decision making by district head is also associated with better educational outcomes (World Bank, 2013).

Besides, the effectiveness of PRODIRA policy has also contributed to improvement in the performance of schools. This corroborates with research by Arsyad (2016), who found that PRODIRA program has had direct and positive inpact on school performance. This is the case because PRODIRA policy orientation that is tailored toward the delivery of educational resources that include school operations, learning, human resources development, and financing student's affairs as well as the improvement in fund management from state-owned enterprises and creative school building facility. State-owned enterprises in this contex means that PRODIRA program is a "quasi" state-owned enterprises . This is because the program facilitates people's access to services based on their ability and socioeconomic status. Edwin Hidayat Abdullah, Deputy Minister for Energy, Logistics, Regions, and Tourism in a seminar entitled State-Owned Enterprise in Campus, explained that realizing sustainable development requires joint efforts from state-owned enterprises, government, community, school or campus and students. Thus, the development of creative schools that became one of the attention of state-owned enterprises (Marwati, 2017).

Improving the quality of higher education performance in Gorontalo Province is more prevalent in all regencies/cities in Gorontalo Province. This was confirmed by Budi Satria as the Board of Directors of Bank BTN in the School for Understanding Nusantara (SMN) Program that was organized by Bank BTN within the framework of BUMN for The country. According to him, one of the indicators of achievement is the fact that students from municipal schools and rich parents no longer dominate the list of $20 \mathrm{SMA} / \mathrm{SMK} / \mathrm{MA}$ high performing students in Gorontalo Province who are selected through a very a tight process rather hail from other areas as well as that include rural areas and poor parents (Saleh, 2017).

Although PRODIRA program honors te right of society to have access to education, it also serves as a"control mechanism" in determining the cost of education activities. If the participation of the local population in financing education increases, PRODIRA program will achieve even greater effectiveness in accelerating the advancement and quality of education in the province. This is because of the limited capacity of the provincial government to provide all the funds necessary to finance high school education in the province, in addition to other priority sectors such as health, infrastructure and others. Based on Antoro's estimates for secondary schools, the cost of non personnel operations for each student per year was in the order of Rp. 3,000,000 (Antoro, 2015). However, the central government is today only able to finance $\mathrm{Rp} 1.4$ million per student a year through School Operational Assistance (BOS). To that end, for PRODIRA policy to fulfill the needs of students' fees that are essential for them to obtain education services, more funding from the community and other sources is needed to supplement and complement the expenditure which Gorontalo provincial government is making to support PRODIRA policy in the province.

\section{CONCLUSION}

PRODIRA policy in Gorontalo Province was formulated and implemented with the purpose of increasing access of Gorontalo population to high school education through the exemption of operational cost payments for students who attend selected high schools in the province. Based on statistics and results of indepth interviews, there is evidence that points to the fact that PRODIRA policy has been 
effective in achieving pre-determined targets of improving the quality of education. Based on several indicators of education performance, Gorontalo education performance at the high school level has been able to catch up with the national average, and even exceeding it, thanks in part to PRODIRA program. The success of the program underscores the importance of strong political will and commitment that Gorontalo provincial government has shown in launching the initiative and sneering that budget allocation is available to finance its implementation. Children who hail from poor families in Gorontalo have been able to access to not only high school education but have been able to attend university education thanks largely to funding, which PRODIRA program has made possible.

As regards suggestions to improve program effectiveness, the author recommends the need for more effort to increase the participation of the public in financing PRODIRA program to complement funding from Gorontalo provincial government which based on estimated costs per student is far from enough. DIKBUDPORA is expected to play an increasingly important role in promoting and encouraging the quality of education in Gorontalo province. To that end, DIKBUDPORA Gorontalo province, needs the support of the local government, central government, the local community and other sources to enhance its human resources capacity, which is necessary for it to render its functions in the province.

As regards, suggestion for future research, the author recommends more research effort in improving the model by increasing the participation of the local population and in general and parents in particular in program design, implementation, monitoring and evaluation.

\section{ACKNOWLEDGEMENTS}

The author would like to thanks the Directorate General of Research and
Development Reinforcement, Ministry of Technology Research and Higher Education of the Republic of Indonesia for the research grant, and Gorontalo Provincial Youth and Sports Culture Education Office for allowing the author access to data used in this research.

\section{REFERENCES}

Adhayani, M., \& Kusumah, R. (2015). Pengaruh Efektivitas dan Kontribusi Penerapan Peraturan Pemerintah Nomor 46 Tahun 2013 Terhadap Penerimaan Pajak (Survei pada KPP Pratama Bandung Cibeunying, KPP Pratama Bandung Tegallega, dan KPP Pratama Bandung Bojonagara), Jurnal Akuntansi Bisnis \& Ekonomi Vol 1 Nomor 1 Tahun 2015, Fakultas Ekonomi. Universitas Widyatama. Bandung.

Ali, M. (2009). Pendidikan untuk pembangunan nasional: menuju bangsa Indonesia yang mandiri dan berdaya saing tinggi. Grasindo. Jakarta

Antoro, Billy (2015). Janji Wajib Belajar(Wajar) 12 Tahun Gratis, Pemda Harus Siapkan Anggaran Pendidikan dari APBD, Source: http://www.dadangjsn.com/2015/05/ janji-wajib-belajar-wajar-12-tahun.html, accessed 23 September 2017

Arsyad, Arfan (2016). The Influence of Knowledge of Management, Principals Attitude and Effectiveness of PRODIRA Toward school Performance in Gorontalo Province, Jurnal Ilmiah Education Management Volume 7 Nomor 1 Desember 2016. Pascasarjana Universitas Negeri Jakarta.

Arwildayanto. (2017). Examining the Effectiveness of Prodira on Improving Human Development Index (A Province of Gorontalo Case), Proceeding the 9th International Conference for Science Educators and Teachers (ICSET), Semarang: Semarang State University, September 13-15, 2017.

Ashari, M. (2016). Analisis Perencanaan

Pembangunan Daerah di Kabupaten 
Lombok Utara (Studi Kasus Perencanaan Partisipatif Tahun 2009-2013). Jurnal Ekonomi dan Kebijakan Publik, 6(2), 163-180. doi.org/10.22212/jekp.v6i2.354 Astri, M., Nikensari, S. I., \& Kuncara, H. (2013). Pengaruh Pengeluaran Pemerintah Daerah pada Sektor Pendidikan dan Kesehatan Terhadap Indeks Pembangunan Manusia di Indonesia. Jurnal Pendidikan Ekonomi dan Bisnis (JPEB), 1(1), 77-102. doi. org/10.21009/JPEB.001.1.5

Atmanti, Hastarini Dwi. (2009). Investasi Sumber Daya Manusia melalui Pendidikan. Jurnal Dinamika Pembangunan (JDP), 2 (Nomor 1), 30-39

Badan Pusat Statistik Provinsi Gorontalo. (2016). Indeks Pembangunan Manusia Provinsi Gorontalo 2010-2016. Grafika Karya. Gorontalo.

Badan Pusat Statistik Provinsi Gorontalo. (2017). Indikator Pendidikan Provinsi Gorontalo 2016. Grafika Karya. Gorontalo .

Boadway, R. 2004. "The Theory and Practice of Equalization," CESifo Economic Studies, 5: 211 $\square$ 254. doi.org/10.1093/ cesifo/50.1.211

Constitution 1945 of the Republic of Indonesia. Secretariat General of the People's Consultative Assembly of the Republic of Indonesia.

Decree of Gorontalo Governor Number 186/07/ $\mathrm{VI} / 2013$ on the Creator of Management Team.

Decree of the Head of DIKBUDPORA Gorontalo Province Number 188.4/ DIKPORA/23.B/SEK/2013 on the Technical Guidance of PRODIRA Implementation. Gorontalo; Dikbudpora Gorontalo Press.

Decree of the Head of DIKBUDPORA Gorontalo Province Number 188.4/ Dikbudpora/172.a/Secondary Education/I/2014 on the Technical Guidance of PRODIRA Implementation Budget Year of 2014. Gorontalo; Dikbudpora Gorontalo Press.
Dinas Dikbudpora Provinsi Gorontalo. (2012). Juknis Program Pendidikan Gratis. Dikbudpora Provinsi Gorontalo.

Dinas Dikbudpora Provinsi Gorontalo. (2014), Petunjuk Teknis Program Pendidikan untuk Rakyat (PRODIRA). Dikbudpora Provinsi Gorontalo.

Dinas Dikbudpora Provinsi Gorontalo, (2016). Laporan Akuntabilitas Kinerja Instansi Pemerintah, Dikbupora Provinsi Gorontalo Tahun 2016. Dikbudpora Provinsi Gorontalo.

Dinas Dikbudpora Provinsi Gorontalo. (2017). Laporan Akuntabilitas Kinerja Instansi Pemerintah Dikbudpora Provinsi Gorontalo 2017. Dikbudpora Provinsi Gorontalo.

Ekosiswoyo. (2016). Kepemimpinan kepala sekolah yang efektif kunci pencapaian kualitas pendidikan, Jurnal Ilmu Pendidikan, 14(2). doi.org/10.17977/ jip.v14i2.24

Fattah, N. (2008). Pembiayaan Pendidikan: Landasan Teori dan Studi Empiris. Jurnal Pendidikan Dasar, 9. 1-4.

Ferdi, W. P. (2013). Pembiayaan Pendidikan: Suatu Kajian Teoritis. Jurnal Pendidikan dan Kebudayaan, 19 (4): 565-578

Frianti, E. (2012). Keefektifan Pelaksanaan Praktik Kerja Industri dalam Rangka Pencapaian Standar Kompetensi pada Kompetensi Keahlian Teknik Pemesinan SMK Negeri 1 Bontang. Dissertation Program Pascasarjana UM

Gorontalo Provincial Regulation Number 2 of 2012 on Medium-Term Development Plan of Gorontalo Province from 2012 to 2017.

Gorontalo Provincial Regulation Number 6 of 2015 on Education Implementation.

Gorontalo Provincial Regulation Number 7 of 2012 on the Implementation of PRODIRA

Gorontalo Provincial Regulation Number 9a of 2012 on Free Education.

Government Regulation Number 19 of 2005 on National Education Standard (State 
Gazette of the Republic of Indonesia Number 41 of 2005, Supplement to State Gazette of the Republic of Indonesia Number 4496). Presidential Instruction Number 7 of 2014

Government Regulation Number 47 of 2008 on Compulsory Education. Jakarta: Depdiknas.

Governor Regulation Number 15 of 2013 on the Guidelines for Funding Management of the Education Implementation for the People in Secondary Schools, Gorontalo Province

Governor Regulation Number 8 of 2012 on the Guideline of Funding Management for School Operational Assistance in SMA/ SMK/MA for Free Education Program in Gorontalo Province.

Handayani, T. (2012). Menyongsong Kebijakan Pendidikan Menengah Universal: Pembelajaran dari Implementasi Wajar Dikdas 9 Tahun. Jurnal Kependudukan Indonesia, 7(1), 39-56. doi.org/10.14203/ jki.v7i1.82

Hoxby, C.M. 2001. "All School Finance Equalizations Are Not Created Equal," Quarterly Journal of Economics 126. 1188 $\square$ 1232. doi.org/ 10.1162/003355301753265552

Karding, A. K. (2008). Evaluasi Pelaksanaan Program Bantuan Operasional Sekolah (BOS) Sekolah Menengah Pertama Negeri Di Kota Semarang. (Doctoral dissertation, program Pascasarjana Universitas Diponegoro).

Law Number 20 of 2003 on National Education System (State Gazette of the Republic of Indonesia Number 78 of 2003, Supplement to the State Gazette of the Republic of Indonesia Number 4301).

Law Number 22 of 1999 on Regional Government. Provincial Government of Jakarta, Bureau of Inter-City and Regional Cooperation.

Law Number 23 of 2014 on Regional Government
Law of the Republic of Indonesia Number 32 of 2004 on Regional Govern-ment. Jakarta: Diperbanyak oleh Departemen Komunikasi dan Informatika

Lunenburg, Frederick C dan Allan C. Ornstein. (2008). Educational Administration: Concepts and Practices: International Journal of Education, 1(1), 1-9.

Marwati, (Saturday, 28 October 2017), UGMBUMN Invite Students to Contribute to National Development, Public Relation, Gadjah Mada University. https://ugm. ac.id/en/news/15040-ugm-bumn.invite. students.to.contribute.to.national. development

Prasojo, L. D. (2012). Financial Resources Sebagai Faktor Penentu Dalam Implementasi Kebijakan Pendidikan. Jurnal Internasional Manajemen Pendidikan, 4(02). Sumber//journal.uny. ac.id/index.php/jimp/article/view/741

Provinsi Gorontalo. 2016. Angka rata-rata Lama Sekolah di Gorontalo Melebihi Nasional. https://www.gorontaloprov. go.id/informasi/berita/prov-gorontalo/ angka-rata-rata-lama-sekolah-digorontalo-melebihi-nasional (diakses 12 Oktober 2017)

Psacharopoulos, G. (2007). Returns to investment in education: A global update. World development Journal, 22(9), 13251343. doi.org/10.1016/ 0305-750X (94) 90007-8

Putri, K. P., Ratnawati, I. (2011). Analisis Pengaruh Brand Image, Biaya Pendidikan, dan Fasilitas Pendidikan terhadap Keputusan Mahasiswa Melanjutkan Studi pada Program Diploma III Fakultas Ekonomi Universitas Diponegoro. Doctoral dissertation, Universitas Diponegoro. Semarang.

Robbin, Stepehen P., (1990), Organization Theory, Structure, Design, and Application, third edition. Prentice Hall, Inc. USA.

Saleh, Wisnawati, (25 Juli 2017) Program Pendidikan Gratis Jadikan Kualitas 
Pendidikan Gorontalo Merata, Humas Pemerintah Provinsi Gorontalo. https:// gorontaloprov.go.id/informasi/berita/ prov-gorontalo/program-pendidikangratis-jadikan-kualitas-pendidikangorontalo-merata

Setiawan, I., dan Hariyono, W. (2013). Hubungan Masa Kerja dengan Kapasitas Vital Paru Operator Empat Stasiun Pengisian Bahan Bakar Umum (SPBU) Kota Yogyakarta Kes Mas: Jurnal Fakultas Kesehatan Masyarakat, 5(3). doi.org/10.12928/kesmas.v5i3. 1068

Siagian, Sondang P. (2001). Kerangka Dasar Ilmu Administrasi. Jakarta: Rineka Cipta.

Sidik, F. (2015). Implementasi Program Jaminan Pendidikan Daerah di Kota Yogyakarta. JKAP (Jurnal Kebijakan dan Administrasi Publik), 19(1), 27-42. doi. org/10. 22146/jkap.7524

Soehartono, Irawan. (2008). Kebijakan Sosial Sebagai Kebijakan Publik. Alfabeta. Bandung.

Sri, E. (2014). Implementasi Kebijakan Bantuan Siswa Miskin (BSM) Tahun Pelajaran 2012/2013 Di Smp Negeri 15 Yogyakarta Provinsi Daerah Istimewa Yogyakarta (Doctoral dissertation, UNY).

Sudjana, N (2005). Metode Statistika. Bandung: Tarsito.

Sugiyono. (2016), Metode Penelitian Kombinasi (mixed methods). Bandung: Alfabeta

Sumar, Warni Tune. (2017). Evaluasi Implementasi Program Pendidikan untuk Rakyat (PRODIRA) di SMA Se-Provinsi Gorontalo. Dissertation Pascasarjana Universitas Negeri Gorontalo (Unpublished)

Suprastowo, P. (2014). Kontribusi Bantuan Siswa Miskin terhadap Keberlangsungan dan Keberlanjutan Pendidikan Siswa.
Jurnal Pendidikan dan Kebudayaan, 20(2), 149-172. doi.org/10.24832\%2Fjpnk. v20i2.135

Syakdiah (2005), Pendanaan Pendidikan di Indonesia, dalam Jurnal Kebijakan dan Administrasi Publik, Vol. 9, No. 2 (November 2005), Yogyakarta: MAP UGM. doi.org/10.22146/jkap.8321.

Thomas R Dye. (1978). Understanding Public Policy 3 rd ed. Englewood Cliff NJ Prenctice Hall

Wahab, S., Abdul. (2007). Pengantar Studi Analisis Kebijakan Negara [Introduction to the Study on Country's Policy Analysis: Rineka Cipta. Jakarta.

Widaningrum, A. (2007). Bekerjanya Desentralisasi pada Pelayanan Publik. JKAP (Jurnal Kebijakan dan Administrasi Publik), 11(1), 43-61. doi.org/10.22146/ jkap.8553.

World Bank, (2013) Tata Kelola Pemerintah Daerah dan Kinerja Pendidikan di Indonesia; Survey Kualitas Tata Kelola Pendidikan pada 50 Pemerintah Daerah, http://www.worldbank.org/in/news/ feature/2013/11/26/local-governanceand-education-performance-in-indonesia Note :

1. An interview conducted on on Friday 16 December 2016. Mr Arshad is the former Head of DIKBUDPORA Gorontalo government and Head of Master Degree Program of Education Management, Post Graduate of Gorontalo State University.

2. Aninterview with Head ofDIKBUDPORA Gorontalo Province conducted on Thursday, March 23, 2017.

3. Interview with Marwati, who is an officials in Public Relations office, Gadjah Mada University, Saturday, 28 October 2017) 